\title{
Costs of corporate bond issue in coal mining companies
}

\author{
Agata Sierpińska-Sawicz', Patrycja Barbara Bąk²
}

ABSTRACT

In Poland, more than $90 \%$ of electricity production is based on coal fuel. Meanwhile, the financial situation of the mining industry is quite challenging. Companies in this sector are in debt, generating losses caused by a sharp drop in coal prices and a simultaneous increase in extraction costs that result from descending into lower levels of coal deposits. At the same time, banks are reluctant to loan money because of the risk of a borrowing entity's default. Increasingly, companies are turning to bond issue to maintain their liquidity and finance development projects. However, bondholders impose conditions in the form of covenants that are often difficult to satisfy, and the strictest relate to the level of a company's indebtedness and ability-to-repay-debt financial ratios.

This article discusses bond issue costs. The authors analyze the bond issue programs of three of the four mining companies operating in Poland. The fourth company did not issue any bonds. Bond issue costs are composed of interest payable to investors, issue preparation and support costs, collateralization costs, and the cost of recording and organizing the sale. The main cost involved in bond issuance is the coupon cost, which depends on the company's financial health and its level of indebtedness, the purpose of the issue, its volume, and the type and quality of the safeguards against the risk of loss of funds invested by bondholders. Bonds issued by coal mining companies are assumed mainly by banks, which demand high interest due to the poor financial condition of the issuers. In addition to interest, companies also pay a capital commitment fee, an arrangement fee and a fee for early redemption. Altogether, in relation to the costs of capital raised through a bank loan, the bond issue results in significantly higher costs of raising capital.

KEY WORDS: level of issue, bond rates, cost of bonds, collateral

JEL Classification: $\quad$ G12, G32

${ }_{1}^{1}$ Poznań University of Economics - Department of Controlling, Financial Analysis and Valuation, Poland; ${ }^{2}$ AGH University of Science and Technology - Department of Economics and Management in Industry, Poland

\section{Introduction}

Funding sources and the costs of their acquisition are of vital importance to the very survival and long-term development of companies in the market. A shortage

Correspondence concerning this article should be addressed to: Agata Sierpińska-Sawicz, Poznań University of Economics Department of Controlling, Financial Analysis and Valuation, Al. Niepodległości 10, 61-875 Poznań, Poland. T: +48 6185437 83, F: +48 6185437 78. E-mail: agata.sierpinska-sawicz@ue.poznan.pl of funds with which to finance current activity upsets a company's short-term financial equilibrium. Lack of development funds, or an excessively high cost of raising them, causes companies to lose their competitive advantage and, in the final analysis, results in their bankruptcy. The choice of sources of funding is particularly important in the mining industry, whose business development is characterized by prolonged investment cycles and relatively long payback periods, which results from the high capital intensity of mining 
activities. Due to the long implementation period of investment projects, their phased-type character and uncertainty of future profitability, mining companies have limited access to bank loans for financing investments. The seasonality of the consumption of certain raw materials and fluctuations in commodity prices caused by the economic climate are also significant issues. To finance their activities, mining companies are increasingly turning to debt capital. During the recent economic crisis, which resulted in a dramatic decrease in profits, these companies issued corporate bonds, treating them as an alternative to the hardto-get bank loans. Additionally, issuance of bonds in tranches is a more flexible funding source than bank loans, which, given the fluctuations in financial results, facilitates companies returning the debt (Sierpińska \& Bąk, 2012).

This article presents an issue that is important from both scientific and practical points of view. During periods of drops in commodity prices, Polish raw material companies lose their creditworthiness, making bond issuance an important funding option. However, conditions imposed by bondholders are often too demanding, preventing companies from seeking this source of funding. Companies cut on investment projects and experience problems when completing investments in progress. This not only prolongs the implementation of the investments but also lowers their rates of return. Additionally, companies lose financial liquidity, and in the case of a failure to pay liabilities in a timely manner, they pay the penalty interest, which increases financial costs.

The authors attempt to assess the cost of bond issuance and the conditions that must be met in order for investors to plough their free assets to corporate bonds. The assessment was made by comparing the metrics of bonds to the average cost of issuing bonds on Catalyst market, which is a segment of the Warsaw Stock Exchange.

\section{Bond issue level in Poland}

The proceeds from the issuance of bonds define a company's debt structure, which is determined by many factors. Undoubtedly, important factors include general economic conditions, inflation, interest rates, tax rates and other factors over which managers have no control but must take into account when selecting sources of funding. Economic conditions, which affect the structure of the debt, are associated with the uncertainty of the demand for products and their prices, the market availability of raw materials and fuels, exchange rate changes, the tax system, and so on. The choice of funding sources is strongly influenced by interest rates because they define the cost of external capital, as well as tax rates that affect the tax shield (Rzeszowski \& Sierpińska, 2012). The choice of types of debt is strongly influenced by several factors, including the company's financial standing, financial risk, returns on capital, type of company management, and the specificity of the industry in which the company operates.

Companies decide to raise funds from a bond issue when banks are reluctant to loan money due to the risk of the entities' default. Furthermore, in line with Basel III, in the coming years, banks will be forced to lend in line with the maturities of their deposits. Therefore, they will grant short-term loans when they themselves hold short-term bank deposits. Meanwhile, coal mining companies require long-term resources to implement their investment projects (Cornett et al., 2011). Under these conditions, bond issues become a particularly attractive source of funding.

The proceeds from a bond issue can be used for any purpose. On an ongoing basis, investors do not control compliance with requirements that surround the effectiveness of underlying investment projects. Bonds bring an added value over an extended period by providing an opportunity for the full financing of large investment projects from the proceeds of the issue. Financing can be flexibly attuned to the investment needs of the company. The issuer may divide the issue into tranches to ensure that they match the financing needs of the investment process, set a date for their redemption, and decide on the form of security that it can pledge. Furthermore, bond issues do not preclude simultaneous use of other forms of financing, such as a bank loan or issuance of shares.

During an economic boom, companies are more willing to reach out for capital from the issue of shares. According to the theory of market timing, if entrepreneurs believe that because of a slump, their shares will be undervalued until the market rebounds, they will postpone the decision to raise capital through the stock market. When the market price of shares on the stock market begins to meet the expectations of the 
Table 1. Growth in the value of funds raised in Poland through bond issues, loans, factoring and leasing in 2003-2013

\begin{tabular}{|c|c|c|c|c|c|c|c|c|c|c|c|c|}
\hline Description & 2003 & 2004 & 2005 & 2006 & 2007 & 2008 & 2009 & 2010 & 2011 & 2012 & 2013 & 2014 \\
\hline $\begin{array}{l}\text { Long-term } \\
\text { bonds in } \\
\text { PLN bn }\end{array}$ & 5.3 & 7.3 & 8.9 & 8.8 & 13.9 & 14.9 & 12.2 & 17.6 & 24.3 & 31.4 & 37.8 & 49,8 \\
\hline $\begin{array}{l}\text { Growth rate, } \\
\% \\
\text { previous } \\
\text { year }=100\end{array}$ & - & 137.7 & 121.9 & 98.9 & 157.9 & 107.2 & 81.4 & 144.6 & 137.5 & 129.7 & 120.4 & 131,7 \\
\hline $\begin{array}{l}\text { Loans and } \\
\text { credit in } \\
\text { PLN bn }\end{array}$ & 126.4 & 129.2 & 123.3 & 127.5 & 144.4 & 182.5 & 233.4 & 220.4 & 221.2 & 264.4 & 270.3 & 311,0 \\
\hline $\begin{array}{l}\text { Growth rate, } \\
\% \\
\text { previous } \\
\text { year }=100\end{array}$ & - & 102.2 & 95.4 & 103.4 & 113.3 & 126.4 & 127.9 & 94.4 & 100.4 & 119.5 & 102.2 & 109,8 \\
\hline $\begin{array}{l}\text { Factoring in } \\
\text { PLN bn }\end{array}$ & 12.0 & 13.2 & 14.2 & 17.0 & 30.7 & 47.9 & 51.4 & 64.2 & 79.4 & 113.1 & 131.0 & 142,8 \\
\hline $\begin{array}{l}\text { Growth rate, } \\
\% \\
\text { previous } \\
\text { year }=100\end{array}$ & - & 110.1 & 107.3 & 119.9 & 180.7 & 155.9 & 107.2 & 125.0 & 123.6 & 142.5 & 115.8 & 109,0 \\
\hline $\begin{array}{l}\text { Leasing in } \\
\text { PLN bn }\end{array}$ & 11.1 & 13.8 & 16.2 & 21.7 & 32.7 & 32.9 & 23.0 & 27.3 & 31.1 & 31.2 & 35.3 & 42,8 \\
\hline $\begin{array}{l}\text { Growth rate, } \\
\% \\
\text { previous } \\
\text { year }=100\end{array}$ & - & 123.9 & 117.6 & 133.9 & 150.7 & 100.8 & 69.8 & 118.7 & 114.1 & 100.3 & 113.0 & 121,2 \\
\hline
\end{tabular}

Adapted from Rola obligacji korporacyjnych w finansowaniu przedsiębiorstw sektora górniczego w Polsce. [The role of corporate bonds in financing mining sector companies]. Gospodarka Surowcami Mineralnymi, 29(1), 141-155 by Sierpińska and Bąk (2013); W tym roku spółki będą więcej pożyczać na rozwój. [This year companies will borrow more for development] by Sajewicz (2014). Retrieved from http://archiwum.rp.pl/artykul/1234503-W-tym-roku-spolki-beda-wiecej-pozyczac-na-rozwoj.html; Dane Statystyczne [Statistic Data] by Związek Polskiego Leasingu. (2015). Available from http://www.leasing.org.pl/statystyki/; Statystyki [Statistics] by Polski Związek Faktorów (2015). Available from http://www.faktoring.pl/index.php?page=6\&id=2015

company's Board regarding its value, the propensity to issue shares increases (Ritter \& Welch, 2002). The opposite trend occurs in periods of an economic downturn or low economic activity in the industry. It is in such circumstances that companies are keen to raise funds from a bond issue. During this period, investors prefer bonds with short maturities of one or two years. Not infrequently, companies roll their debts over, i.e., in place of the redeemed bonds, they place a new issue of a similar value on the market. Through fundraising flexibility, they ensure a steady supply of funds, allowing them to maintain liquidity at an appropriate level (Waśniewski, 
2012). The flexibility of bonds is also reflected in the fact that they may include the option of the issuer's early redemption. This is cost effective, especially in periods of expected declines in interest rates. Thus, using funds from the issue of lower priced securities, a company can refinance its debt through an early redemption of higher interest securities. In 2014, a series of interest rate cuts prompted businesses to take advantage of this procedure. Moreover, investors are keen to invest surplus funds in corporate bonds because these offer a higher interest rate than bank deposits.

The amount of bond issues in relation to other sources of funding is presented in Table 1. The figures in the table show that the pace of change that surrounds fundraising through the issue of bonds was highly volatile, becoming increasingly so each year. The largest increase in the value of the issued bonds in the previous year was reported to be $57 \%$ in 2007 . In 2008 -2014, which was a period of decline in corporate investment, the increase in the value of issues was significant.

During the period 2003-2013, the increase in bank debt was markedly lower than the increase in funds from bond issues. Only 2013 witnessed a nearly 10\% increase in debt, compared to an over 30\% increase in the value of the issued bonds. Factoring shows a high growth rate. In 2012, companies raised $42.5 \%$ more funds through factoring than in the previous year. The proceeds from factoring and partly from bond issues were allocated to the maintenance of financial stability.

Leasing grew at a slower pace, and it was mainly used by companies to pay for fixed assets. During an economic downturn, companies are very wary of investing in the development of production capacity. When demand grows, companies use existing production capacity first, and only then do they increase this capacity, which contributes to the creation of new jobs. However, in raw material companies, investment cannot be postponed due to the long investment cycle of mining projects.

In Poland, bond issuance is not only an option for stable companies, such as energy, construction or telecommunications companies, but also for businesses in high-growth sectors, such as renewable energy, biotechnology, medicine and pharmaceuticals. In a bid to tap into EU funding, these companies must have their own funds to contribute to project implementa- tion, hence their decision to issue bonds. Coal mining companies have been issuing bonds for the previous two years, the proceeds from which have been used to finance both operating activities and development.

\section{Research methods and information sources}

To assess the costs and conditions of bond issuance for coal mining companies, the authors applied a comparative analysis. Based on data derived from the Catalyst website, analyses conducted by the consultancy firm $\mathrm{PwC}$ and the authors' own analyses, the authors assessed the costs of bond issuance to mining companies against the average cost of bond issuance in the Polish debt market. There are four coal mining companies in Poland. The research was conducted in three companies, which account for $75 \%$ of the sample. The authors analyzed bond issue programs prepared for Jastrzębska Spółka Węglowa (JSW), Kompania Węglowa and Katowicki Holding Węglowy. However, not every program was implemented, due to the high costs of issuance, program preparation and execution, and additional conditions known as covenants, which markedly reduced the flexibility of the companies. At the end of 2014, interest rates in Poland were down to 2\%. By March 2015, the Monetary Policy Council further lowered the rates to $1.5 \%$. Such low interest rates prompted companies to benefit more from the debt market. However, the overly restrictive conditions of bond issuance led two of the companies to abandon this method of borrowing.

The detailed provisions of bond issues were confidential. Therefore, this paper presents the general bond issue conditions of three issuance programs that were prepared for mining companies. By factoring into consideration the specifics of the coal mining companies' operations, these programs allowed one to assess the total cost of this form of fundraising. The terms and conditions of the bond issues were highly determined by the issuer's financial standing. Hence, the financial conditions of three mining companies were examined. Table 2 provides the structure of the companies' assets and liabilities.

As indicated by the data in Table 2, the financial structure of all three surveyed companies began to worsen in 2012. The share of equity in total liabilities decreased. In 2014, Kompania Węglowa had a nega- 
Table 2. The structure of assets and liabilities in mining companies issuing bonds in years 2010-2014

\begin{tabular}{|c|c|c|c|c|c|}
\hline Description & 2010 & 2011 & 2012 & 2013 & 2014 \\
\hline \multicolumn{6}{|l|}{ KOMPANIA WĘGLOWA } \\
\hline \multicolumn{6}{|l|}{ Asset's structure, $\%$} \\
\hline Fixed assets, $\%$ & 68,0 & 66,6 & 69,3 & 74,2 & 74,8 \\
\hline Current assets, $\%$ & 32,0 & 33,4 & 30,7 & 25,8 & 25,2 \\
\hline \multicolumn{6}{|l|}{ Liabilities structure, $\%$} \\
\hline Equity, $\%$ & 21,0 & 24,7 & 13,9 & 4,9 & $(4,0)$ \\
\hline Liabilities and provisions for liabilities, $\%$ & 79,0 & 75,3 & 86,1 & 95,1 & 104,0 \\
\hline \multicolumn{6}{|l|}{ KATOWICKI HOLDING WĘGLOWY } \\
\hline \multicolumn{6}{|l|}{ Asset's structure, $\%$} \\
\hline Fixed assets, $\%$ & 82,0 & 83,0 & 72,1 & 83,6 & 83,5 \\
\hline Current assets, $\%$ & 18,0 & 17,0 & 27,9 & 16,4 & 16,5 \\
\hline \multicolumn{6}{|l|}{ Liabilities structure, $\%$} \\
\hline Equity, \% & 29,7 & 31,9 & 26,7 & 24,8 & 11,6 \\
\hline Liabilities and provisions for liabilities, \% & 70,3 & 68,1 & 63,3 & 75,2 & 88,4 \\
\hline \multicolumn{6}{|l|}{ JASTRZĘBSKA SPÓŁKA WĘGLOWA } \\
\hline \multicolumn{6}{|l|}{ Asset's structure, $\%$} \\
\hline Fixed assets, $\%$ & 70,4 & 68,2 & 70,4 & 74,2 & 85,1 \\
\hline Current assets, $\%$ & 29,6 & 31,8 & 29,6 & 25,8 & 24,9 \\
\hline \multicolumn{6}{|l|}{ Liabilities structure, $\%$} \\
\hline Equity,\% & 57,2 & 65,2 & 62,6 & 60,2 & 47,3 \\
\hline Liabilities and provisions for liabilities, $\%$ & 42,8 & 34,8 & 37,4 & 39,8 & 52,7 \\
\hline
\end{tabular}

Adapted from Financial Statements 2010-2014 by Kompania Węglowa S.A. (2015). Available from http://bip.kwsa.pl/?id_ kat=27; Financial Statements 2010-2014 by Katowicki Holding Węglowy S.A. (2015). Available from http://www.khw.pl/bip/ wyniki.html; Investors Relations by Jastrzębska Spółka Węglowa. (2015). Available from http://www.jsw.pl/relacje-inwestorskie

tive level of equity. Total liabilities were $4 \%$ higher than total assets, indicating an equity deficiency of $4 \%$. For Katowicki Holding Węglowy, the share of equity decreased from $26.7 \%$ in 2012 to $11.6 \%$ in 2014 . JSW had the best capital structure of all researched companies. Its equity level decreased by 15.3 percentage points, from $62.6 \%$ in 2012 to $47.3 \%$ in 2014 . The companies' losses caused their equity to lessen.
In addition to changes in the structure of financing sources, the explicit worsening of the mining companies' financial situations was revealed by the financial results, which are presented in Table 3. The largest decrease in financial results appeared in 2014. Kompania Węglowa generated a loss of 1 bn PLN. Due to the lack of supplementary capital to cover losses, the loss was 2.7 times larger than the level of equity. In 2014, 
Table 3. Financial results of Polish mining companies issuing bonds

\begin{tabular}{|c|c|c|c|c|c|}
\hline Description & 2010 & 2011 & 2012 & 2013 & 2014 \\
\hline \multicolumn{6}{|l|}{ KOMPANIA WĘGLOWA S.A. } \\
\hline Assets (PLN mn) & 11439,7 & 11852,0 & 12136,0 & 13049,4 & 9324,2 \\
\hline Equity(PLN mn) & 2408,7 & 2877,7 & 1682,1 & 637,8 & $(368,1)$ \\
\hline Sales revenues(PLN mn) & 10131,3 & 11919,7 & 10720,6 & 9720,1 & 7751,0 \\
\hline Net profit/loss (PLN mn) & 30,9 & 554,5 & 170,8 & $(699,0)$ & $(1005,9)$ \\
\hline ROS, $\%$ & 0,30 & 4,65 & 1,59 & $(9,72)$ & $(12,78)$ \\
\hline $\mathrm{ROA}, \%$ & 0,27 & 4,68 & 1,41 & $(5,36)$ & $(10,79)$ \\
\hline $\mathrm{ROE}, \%$ & 1,28 & 19,27 & 10,15 & $(109,59)$ & $(273,27)$ \\
\hline \multicolumn{6}{|c|}{ Katowicki Holding Węglowy S.A. } \\
\hline Assets (PLN mn) & 4757,3 & 4744,7 & 5456,2 & 5674,5 & 5177,2 \\
\hline Equity(PLN mn) & 1421,5 & 1514,2 & 1458,2 & 1483,4 & 597,8 \\
\hline Sales revenues(PLN mn) & 3597,2 & 3807,6 & 3644,6 & 3647,3 & 3389,0 \\
\hline Net profit/loss (PLN mn) & 31,3 & 249,7 & 58,6 & 30,4 & $(496,1)$ \\
\hline $\mathrm{ROS}, \%$ & 0,87 & 6,54 & 1,61 & 0,83 & $(14,64)$ \\
\hline $\mathrm{ROA}, \%$ & 0,66 & 5,26 & 1,07 & 0,53 & $(9,58)$ \\
\hline $\mathrm{ROE}, \%$ & 2,20 & 16,49 & 4,02 & 2,05 & $(82,99)$ \\
\hline \multicolumn{6}{|c|}{ Jastrzębska Spółka Węglowa S.A. } \\
\hline Assets (PLN mn) & 9106,1 & 13617,0 & 14067,1 & 13862,0 & 15369,3 \\
\hline Equity(PLN mn) & 520,6 & 8443,4 & 8579,0 & 8351,6 & 7267,5 \\
\hline Sales revenues(PLN mn) & 6172,4 & 9378,0 & 8821,0 & 7632,2 & 6814,9 \\
\hline Net profit/loss (PLN mn) & 1158,9 & 2086,0 & 988,1 & 82,2 & $(657,1)$ \\
\hline $\mathrm{ROS}, \%$ & 18,77 & 22,24 & 11,20 & 0,98 & $(9,64)$ \\
\hline $\mathrm{ROA}, \%$ & 12,73 & 15,32 & 7,02 & 0,59 & $(4,28)$ \\
\hline $\mathrm{ROE}, \%$ & 22,6 & 24,7 & 11,52 & 0,98 & $(9,04)$ \\
\hline
\end{tabular}

Adapted from Financial Statements 2010-2014 by Kompania Węglowa S.A. (2015). Available from http://bip.kwsa.pl/?id_ kat=27; Financial Statements 2010-2014 by Katowicki Holding Węglowy S.A. (2015). Available from http://www.khw.pl/bip/ wyniki.html; Investors Relations by Jastrzębska Spółka Węglowa. (2015). Available from http://www.jsw.pl/relacje-inwestorskie

the loss for Katowicki Holding Weglowy amounted to nearly 0.5 bn PLN, which accounted for $83 \%$ of the company's equity. In the same year, JSW also recorded a loss; however, the decrease in equity was minor compared to the two other companies.
Generated losses caused negative return ratios, loss on assets, loss on equity and loss on sales ratios. For Kompania Węglowa, loss on sales amounted to $9.7 \%$ in 2013 and $10.8 \%$ in 2014. Loss on equity increased from $109.6 \%$ to $273.3 \%$. Based on the legal provisions of the 
Table 4. Level of coal extraction, average prices of coal, and average cost of coal extraction in the Polish mining industry

\begin{tabular}{lcccccc}
\hline Description & $\mathbf{2 0 1 0}$ & $\mathbf{2 0 1 1}$ & $\mathbf{2 0 1 2}$ & $\mathbf{2 0 1 3}$ & $\mathbf{2 0 1 4}$ & $\begin{array}{c}\text { Dynamics,\% } \\
\mathbf{2 0 1 1}=\mathbf{1 0 0}\end{array}$ \\
\hline Coal extraction (thous. Mg) & 76153,8 & 75667,8 & 79234,2 & 76466,3 & 72500,0 & 95,8 \\
Coking coal price (PLN/Mg) & 582,75 & 811,78 & 625,70 & 473,34 & 410,36 & 50,60 \\
Steam coal price (PLN/Mg) & 246,70 & 266,93 & 315,27 & 267,58 & 234,39 & 87,80 \\
Average prices of coal in JSW & 498,73 & 583,26 & 500,90 & 386,77 & 338,95 & 58,10 \\
Coke price (PLN/Mg) & 1028,81 & 1197,93 & 970,20 & 758,50 & 668,18 & 55,80 \\
Average price of coal in Poland (PLN/Mg) & 298,40 & 341,30 & 340,00 & 292,80 & 278,70 & 81,60 \\
Average cost of coal extraction (PLN/Mg) & 270,00 & 286,70 & 304,60 & 301,40 & 312,20 & 108,90 \\
Accumulation (PLN/Mg) & 28,40 & 54,60 & 35,70 & $-8,60$ & $-33,50$ & 161,30 \\
\hline
\end{tabular}

Adapted from Inside Statistics by The Mineral and Energy Economy Research Institute of the Polish Academy of Sciences (2015). Inside Statistics. Available from http://www.min-pan.krakow.pl/en/; Investors Relations by Jastrzębska Spółka Węglowa. (2015). Available from http://www.jsw.pl/relacje-inwestorskie

Commercial Companies Code, this company should file for bankruptcy. For Katowicki Holding Węglowy, loss on sales (negative ROS) accounted for $14.6 \%$, and loss on equity (negative ROE) accounted for $9.6 \%$ in 2014. In turn, the return on sales for JSW declined from $22 \%$ in 2011 to $9.6 \%$ in 2014 . In 2011, the company's return on assets amounted to $15 \%$, while return on equity was nearly $25 \%$. In the final examined year, these ratios amounted to $4.3 \%$ and $9.0 \%$, respectively. Large fluctuations in the mining companies' financial results and profitability indicate that they have limited access to bank loans. Under these conditions, they turn to a more flexible source of funding, namely bonds.

The decrease in coal prices was the basic reason for the worsening financial results of mining companies (Table 4). In the 5-year analyzed period, the prices of coal were highest in 2011, making that year a benchmark value in the table. The average prices of coal in years 2011-2014 dropped by nearly $20 \%$.

Table 4 also presents the prices of coal that were set by JSW itself, as the company influenced the average prices of coal in Polish mining. JSW extracts coking coal, the price of which is much higher than the price of steam coal. In 2011, coking coal cost up to 812 PLN per tonne, while steam coal was 267 PLN/Mg. In subsequent analyzed years, this price ratio deterio- rated. Hence, in 2014, the average price of steam coal amounted to $234 \mathrm{PLN} / \mathrm{Mg}$, whereas the average price of coking coal declined to $410 \mathrm{PLN} / \mathrm{Mg}$. The steam coal extracted by Kompania Węglowa and Katowicki Holding Węglowy had an approximate caloric value; thus, its price oscillated around the same amount.

An important factor influencing the financial results of mining companies was an increase in coal extraction costs. During the analyzed period, the cost reached nearly $9 \%$, which led to losses due to the drop in coal prices. In 2011, accumulation on the sale of one tonne of coal amounted to nearly 55 PLN. Four years later, loss on the sale of one tonne of coal exceeded 33 PLN. Due to shortages of coal resources, mines were forced to dig into lower coal deposit levels, which increased the cost of extraction. Additionally, fixed costs, i.e., salaries and overhead expenses, which do not depend on production scale, accounted for more than half of the extraction costs. In 2014, production declined by $4.2 \%$, causing an increase in the average cost of mining by $3.6 \%$. During this period, companies were unable to explore new extraction walls at lower levels of coal deposits due to the lack of investment funds.

The conducted analysis indicates that, as a result of the large drop in coal prices and increase in extraction 
costs, mining companies suffered from worsened conditions for raising funds. The terms and conditions of bondholders for capital lending will be presented later in the article.

\section{Analysis of bond interest rates on Catalyst market}

The primary cost involved in a bond issue is the interest paid to investors. Each type of capital has its own cost level. Hence, differences in the cost of acquisition for a given type of capital afford companies an opportunity to design the best structure of their debt that will be the lowest cost of acquisition (Pratt \& Grabowski, 2014).

Depending on the method of interest calculation, one can distinguish the following: bonds with a fixed coupon rate (interest rate), bonds with a variable coupon rate, indexed bonds, and zero-coupon bonds (Golawska-Witkowska, Rzeczycka, \& Zalewski, 2006; Sierpińska \& Bąk, 2013):

In addition to interest-bearing bonds, which are referred to as classic corporate bonds, issuers also put on the market instruments that offer other benefits, e.g., convertible bonds with a right of conversion into the issuer's shares, and bonds convertible into another entity's shares (Vernimmen et al., 2014).

On the Polish market, the interest rate on bonds is generally determined based on $3 \mathrm{M}$ or $6 \mathrm{M}$ WIBOR (i.e., interbank market rates), to which a margin is added. In Poland, the most commonly issued bonds are those with a variable coupon rate, with margins ranging from $3.3 \%$ to $6.5 \%$. The average margin in 2014 stood at $4.12 \%$ above WIBOR (Gałka, 2015).

Throughout the life of the bond, a fixed interest rate is the preferred choice for issuers who do not want to be exposed to the risk of interest rate fluctuations. For issuers, a fixed rate is beneficial when financing investment projects with a low rate of return on capital. This approach will not make investment projects unprofitable during times of significant interest rate hikes. To inspire investor interest in bonds with a fixed interest rate, this rate should take into account future growth expectations, and it should be set at a level that is higher than the prevailing rate at the time of issue. For issuers, bonds with a fixed interest rate are especially attractive at times of low interest rates. However, in a bid to capitalize on interest rate hikes following a period of economic downturn, investors prefer bonds with a variable interest rate.

The size of interest and profit margin for investors is determined by such factors as the company's financial situation, its debt level, recognition in investor circles, market position, scale of operations, the size of the bond issue, its purpose, and the nature and quality of the underlying security. Investors expect a higher margin whenever the proceeds from the issue will be used to finance current operations or repay existing debt. They tolerate lower margins when the funds are used to finance development projects. When determining the interest rate and the profit margin, a key element to take into account is the value and type of security pledged as collateral. Secured bonds may have a lower interest rate, especially when they are backed by a mortgage on the company's property. Considerable impact on the bond's interest rate is exerted by the situation in the financial markets. During a downturn, the risk of issuers' bankruptcy is higher, and hence, issuers must offer higher interest to investors.

The interest rate also depends on whether the issue is made by a public company listed on the capital market, or by a non-public company unknown to a wider circle of investors. The latter company must offer a higher profit margin than the former. The cost of raising capital from a bond issue depends on ratings granted by competent institutions. The lack of such ratings, which are required especially by foreign investors, may increase the cost of raising capital in relation to the costs of capital raised through a bank loan. The bond rating, which is an independent and objective assessment of the credit risk posed by an already indebted entity or one incurring debt in the financial markets, is the responsibility of rating agencies. The issuer's inclusion in a particular group allows investors to gauge their risk premium for investing in bonds issued by a given entity. A high rating confirms an issuer's good financial standing, allowing the issuance of bonds at a relatively low interest rate (Dębski, 2010). The market is dominated by three major rating agencies: Moody's, Standard \& Poor's, and Fitch Ratings. The agencies are used by corporations that place high value issues on the international debt market. Due to the high costs involved in obtaining a credit rating, small- and medium-sized companies do not approach such agencies. Instead, they can take advantage of do- 

According to Smith and Warner (1979), the use of covenants entails additional costs but also diminishes the financing risk and thereby reduces the cost of capital. According to these researchers, an optimal set of covenants exists for any company, ensuring a balance between the costs of implementation and enforcement of covenants and the benefits of reducing the investment risks for external entities (Smith \& Warner, 1979). Financial covenants are based on parameters of the assessment of the borrower's financial condition. Billett, King and Mauer (2007) proposed a model consisting of 15 variables measuring the level of covenant restrictiveness and relating it to indebtedness, dividends, restrictions on the disposal of assets, level of investment, restrictions on the issuance of bonds, maintenance of a certain level of earnings, mergers and acquisitions, and maintenance of rating. In agreement with other authors, Śmieja and Pauka (2013b) argue that companies with a larger number of effective covenants are less likely to go bankrupt because their boards must avoid risky decisions, specifically because of covenants. Covenants may also relate to general risk, the condition of the company's industry, or the company's management and changes in its ownership structure.

\section{Conditions underlying bond issuance in coal mining companies}

To assess the costs and conditions of corporate bond issues in companies of raw materials, the authors have carried out an analysis of selected bond issues in the last two years. Bond issue programs were prepared and implemented by legal and financial advisers. Their work costs approximately $1 \%$ of the value of the issues.

Bonds bear interest at WIBOR $3 \mathrm{M}$, plus a margin ranging between 270 and 350 basis points p.a., depending on the tranche. This means that as of the date of issue, interest will be paid on a quarterly basis and will be charged based on the amount of bonds issued and outstanding. In the case of a failure to pay interest in a timely manner, a statutory interest rate $(8.5 \%$ in 2015) will accrue. This poses a risk of increased costs of capital.

In addition to interest, companies pay a fee for the commitment of capital (for the unused capital made available to the company), which, depending on the tranche, costs 50-70 basis points, an arrangement fee of $80-100$ basis points, and a fee of $50-65$ basis points for early redemption of the bonds with money raised from other debt instruments. The issuance program provides for the redemption of individual tranches of bonds in the subsequent years of the 2015-2020 period. The largest amount to be redeemed falls in the last two years of the program, increasing the total costs of such issues.

The series of floating-rate bonds issued are secured at $110-130 \%$ of their value. Therefore, the full amount of the issue and interest on capital are secured. The bonds are secured by a mortgage on the issuing company's property, plant and equipment, registered pledges on receivables held in accounts kept by banks (underwriters), registered pledges on receivables from major long-term agreements for the supply of coal, pledges on coal stocks, and guarantees by subsidiaries. Collateral pledged by the Treasury is used when the issuer is an entity owned by the Treasury. Bond issues made by Kompania Węglowa and Katowicki Holding Węglowy featured this type of collateralization.

The terms and conditions of the bond issue also contain covenants governing the company's disposal of assets, the level of its debt, the conditions of bond redemption, its compliance with financial ratios, and management's obligations to ensure the audit of financial statements and the application of certain accounting principles.

The most commonly used financial ratios, which are defined in the terms and conditions of issue, include the net debt/EBITDA ratio, the Debt Service Coverage Ratio (DSCR) and Projected Cash Flow.

In the issues under consideration, the Net Debt/ EBITDA ratio ranges from 2.0 to 3.5 . When the metric stands at 2.0, the net debt (debt less cash holdings) should not exceed the generated operating profit plus depreciation and amortization by more than a factor of two. Once the ratio is exceeded, bondholders often demand the payment of financial penalties. For coal mining companies, the level of this ratio may depend on how these companies account for certain business operations. Companies using IAS, a reporting requirement to which listed companies are subject, record the exchange difference on exported raw materials as part of their basic sales revenues, while exchange differences on the importation of materials are recorded as operating costs. In companies recording business operations 
pursuant to the provisions of the Accounting Act, these differences are recognized in financial revenue and finance costs. This indicates that some of the results of operations are not accounted for in the operating profit. Therefore, it would be necessary either to adjust the operating profit so that it accounts for elements of financial revenue and finance costs, or determine the operating profit starting with gross profit.

Another acute problem related to meeting the standards set by this ratio concerns fund allocation. If the proceeds from the issuance are used to finance current operations, then asset depreciation will not increase, leading to an excessive rise in the Net debt/EBITDA ratio, although the debt level will not rise. On the other hand, debt financing through a bond issue increases depreciation, thus improving the ratio. This ratio should be differentiated and depends on the allocation of funds from the bond issue. The ratio level of 2.0, as required by investors, seems to be too high, posing the risk of non-compliance. The risk is even more acute in raw material companies due to the high volatility of commodity prices on world markets. For example, a decline in coal prices caused the coal companies to generate losses. In certain companies, EBITDA is less than the level of depreciation. Companies can maximize the value of depreciation by charging extraordinary depreciation costs for the closure of mines. However, they will reduce their net profit, which may increase the risk of immediately calling in the debt. The solution to this problem depends on the specific conditions of the bond issue, which are of a confidential nature. Often the terms and conditions of the bond issue stipulate that the company shall be subject to a penalty for failure to comply with financial ratios, which increases the costs of bond issuance. The total cost of the bond issue may then be much higher than the cost of a syndicated loan. The company may comply with the net debt/EBITDA ratio requirement by controlling the level of its debt. However, under difficult market conditions, this could lead to loss of liquidity. In addition, the impossibility of taking on extra debt to complete a project that is already in progress may lead to huge losses due to a breach of contracts for the supply of raw materials. This is clearly illustrated by the problems posed by the delay in completion of the gas terminal in the port city of Świnoujście. Therefore, the terms and conditions of bond issuance should provide for the net
debt/EBITDA ratio to be within a reasonable range, rather than at a fixed level, accounting for the nature of the coal companies' business, the seasonality of coal consumption, and fluctuations in financial results due to cyclical changes in the price of coal. When the interest is accrued on a quarterly basis, the net debt/EBITDA ratio is calculated on the last day of each quarter until the redemption date; and when interest is accrued semi-annually, the ratio is calculated on the last day of each half-year. Bondholders usually demand that the calculations be made on the basis of audited values that originate in financial statements, furthering that the annual values of this ratio be verified by an auditor reviewing the annual financial statements.

The second parameter laid down in the terms and conditions of bond issues mandates that DSCR be between 1.1 and 1.3. DSCR is a ratio of cash available to service the debt to the amount of debt consisting of interest and principal, or a given tranche redeemed in a given quarter. A debt level of 1.3 means that if the company is to timely meet its other obligations, e.g., remuneration or materials and services payables, the funds available to service the debt should be $30 \%$ higher than the amount to be repaid by the company. As in the case of the previous ratio, this ratio is subject to audit. The method of its calculation must be in accordance with a formula set forth in the bond agreement, and it must be submitted to the Payments Agent, who controls the level of the indicators laid down in the terms and conditions of the bond issue during the accrual of interest.

The third parameter, called the Projected Cash Flow ratio, is laid down within the range of 1.1 to 1.3 . This metric measures the relationship between revenues from contracts pledged as security for the bonds and the maximum amount of the bond issue program. It is determined based on values projected at least 1.52.0 years ahead. Once its value is fixed at 1.3 , it must not fall below that number. With the ratio set at this level, it can be concluded that the conditions of the issue are difficult to satisfy, but everything depends on the method of calculating the values that are the basis for its calculation. If the issue is secured by mortgages on property, plant and equipment, these assets must be valuated, and their future value disclosed in future periods in line with market conditions prevailing at the future time. Hence, it is assumed that the proceeds 
generated by the collateral should be at least $20-30 \%$ higher than the value of the issuance program. In the face of the economic downturn and uncertainty about future economic circumstances, changes in property prices typically lead bondholders to require different forms of security and demand the proceeds from the sale of products manufactured by the company. However, the allocation of funds from current revenues generated by sales of products carries a risk of shortage of funds that are needed to meet liabilities that enable restoration of production processes. This risk is particularly high in the coal mining industry, where employee salaries account for approximately $55 \%$ of coal production costs. A failure to pay company employees in a timely manner leads to social unrest and additionally creates political risk because coal mining companies are state-owned. The problem will not be solved by the privatization companies because this will increase risk in the area of energy security.

Limitations imposed by the terms and conditions of bond issuance also concern the level of investment that companies can undertake before the bond's maturity, disposal of assets held, permissible debt level or transfer of funds to subsidiaries. Regulations in these areas differ for each analyzed issue. For example, the provisions governing property, plant and equipment fix the amount of assets that can be sold or put to use by other entities. Such provisions can hinder the use of funds from the sale of assets to service debt. In the face of declining performance, companies could use leaseback more widely in order to retain their ability to redeem individual tranches of bonds, but they do not have the freedom to dispose of their own assets. In addition, bondholders want to have priority over shareholders for access to funds that are generated to service debt. Hence, the limiting conditions of bond agreements often contain provisions concerning the allocation of profit. In such cases, for the period from bond issuance until its redemption, the dividend policy must incorporate provisions that stipulate that the company shall not pay dividends higher than a specified amount, e.g., 30\% of any of the generated profit, or the company shall not pay them at all if its profits fall below a specified amount. These provisions are the result of projected cash flows and a need to comply with the above-mentioned financial ratios at a level mandated by bond contracts.

\section{Summary}

For mining companies, it must be emphasized that raising funds from bond issue is more expedient than bank loans. The prolonged cycle of implementing investment projects lasts for several years. Thus, companies can flexibly adjust the issue tranches to their financial needs and investment realization phases. Terms and conditions of bond issue for the mining industry were compared to average terms of bond issuance on Catalyst market, where average bond interest rates amounted to WIBOR $3 \mathrm{M}$, plus a 3-6\% margin. This markup was due to issuance of unsecured bonds that were of higher risk than covered bonds.

Issue programs prepared for mining companies assumed variable interest rates at WIBOR $3 \mathrm{M}$, plus a margin of 2.7 to $3.5 \%$. On Catalyst market, the costs of preparing the issue for larger offers ranged from 1.5 to $2 \%$ of the total value of the issue. For mining companies, the latter oscillated near $2 \%$. Besides these two cost components, mining companies had to pay a capital commitment fee of 1.5 to $0.7 \%$ (depending on the tranche), an arrangement provision of 0.8 to $1 \%$, and a fee of 0.5 to $0.65 \%$ for early redemption when using funds raised from other debt instruments. Issued bonds are secured at the level of 110 to $130 \%$ of the total value of the issue by different types of collateral, such as mortgages on the issuer's tangible property, registered pledges on receivables from major long-term agreements for the supply of coal, pledges on coal stocks, and guarantees by subsidiaries. Additionally, several strict covenants were created, relating to the level of indebtedness monitored by ratios: EBITDA (2.0-3.5) and DSCR (1.1-1.3), as well as to restrictions on profit distribution, governing the company's disposal of assets or funds transferred to subsidiaries. Meeting the overly restrictive expectations of bondholders led companies to withdraw from issuing certain tranches of bonds.

\section{References}

Billett, M. T., King, T. D., \& Mauer, D. C. (2007). Growth opportunities and the choice of leverage, debt maturity, and covenants, The Journal of Finance, 62(2), 697-730.

Cornett, M. M., McNutt, J. J., Strahan, P. E., \& Tehranian, H. (2011). Liquidity risk management and credit supply in the financial crisis, Journal of Financial Economics, 101(2), 297-312. 
Dębski, W. (2010). Rynek finansowy i jego mechanizmy. [Financial Market and its mechanisms]. Warszawa: Wydawnictwo Naukowe PWN.

Gałka, T. (2015). Ewolucja rynku obligacji korporacyjnych w Polsce [Evolution of corporate bonds market in Poland]. Retrieved from: http://www.caseresearch.eu/sites/default/files/T.Ga\%C5\%82ka_ prezentacja.pdf

Golawska-Witkowska, G., Rzeczycka, A., \& Zalewski, H. (2006). Zarządzanie finansami Przedsiębiorstwa [Corporate Finanance Managment]. Bydgoszcz: Oficyna Wydawnicza Branta.

Grant Thornton (2013, December). Catalyst Report Summary and Growth Perspectives ( $2^{\text {nd }}$ Ed.). Retrieved from http://www.gpwcatalyst.pl/pub/files/ materialy_do_pobrania/Catalyst $\% 20$ Report $\% 20$ December\%202013\%20FINAL.pdf

Jastrzębska Spółka Węglowa. (2015). Investors Relations. Available from http://www.jsw.pl/relacjeinwestorskie

Katowicki Holding Węglowy S.A. (2015). Financial Statements 2010-2014. Available from http:// www.khw.pl/bip/wyniki.html

Kompania Węglowa S.A. (2015). Financial Statements 2010-2014. Available from http://bip.kwsa.pl/?id_ kat $=27$

Pauka, M., \& Śmieja, N. (2013a). Zastosowanie konwentów w warunkach emisji obligacji - badania empiryczne wśród emitentów z branży developerskiej w Polsce [Using debt covenants of put options embedded in bonds- an empirical research among bond issuers from real estate development industry in Poland]. Zeszyty Naukowe Uniwersytetu Szczecińskiego, Finanse, Rynki Finansowe, Ubezpieczenia, 62, 399-409.

Polski Związek Faktorów. (2015). Statystyki [Statistics]. Available from http://www.faktoring.pl/index.php?page $=6 \&$ id $=2015$

Pratt, S. P., Grabowski, R. J. (2014). Cost of capital: applications and examples ( $5^{\text {th }}$ ed). Hoboken, New Jersey, NJ: Wiley.

Ritter, J. R., Welch, I. (2002), A. Review of IPO activity, pricing and allocations. The Journal of Finance, 57(4), 1795-1828.

Rzeszowski, P., Sierpińska, M. (2012). Financing structure of enterprises in the metal industry in Poland between 2000 and 2010. Contemporary Economics, 6(3), 66-75.
Sajewicz, M. (2014, March 14). W tym roku spółki będą więcej pożyczać na rozwój. [This year companies will borrow more for development]. Retrieved from http://archiwum.rp.pl/artykul/1234503-Wtym-roku-spolki-beda-wiecej-pozyczac-na-rozwoj.html

Sierpińska, M., Bąk, P. (2012). Financial structure of mining sector companies during an economic slowdown. Archives of Mining Sciences, 57(4), 1089-1100.

Sierpińska, M., Bąk, P. (2013). Rola obligacji korporacyjnych w finansowaniu przedsiębiorstw sektora górniczego w Polsce [The role of corporate bonds in financing mining sector companies]. Gospodarka Surowcami Mineralnymi, 29(1), 141-155.

Smith, C.W., Warner J. B. (1979). On financial contracting: An analysis of bond covenants. Journal of Financial Economics, 7(2), 117-161.

Śmieja, N., \& Pauka, M. (2013b). Analiza kowenantów $\mathrm{w}$ obligacjach korporacyjnych emitowanych przez niebankowe spółki z branży finansowej. [Covenants analysis in corporate bonds issued by the debt collection firms]. Annales Universitatis Mariae Curie-Skłodowska, Sectio H Oeconomia, 47(3), 551-561.

Vernimmen, P., Quiry, P., Dallocchio, M., Le Fur, Y., Salvi, A. (2014). Corporate Finance. Theory and Practice $\left(4^{\text {th }}\right.$ ed.). John Wiley \& Sons. West Sussex, UK.

The Mineral and Energy Economy Research Institute of the Polish Academy of Sciences (2015). Inside Statistics. Available from http://www.min-pan. krakow.pl/en/

Waśniewski, P. (2012). Wpływ zakresu ujawnień na identyfikację ryzyka kredytowego inwestycji w obligacje korporacyjne. [Influence of exposure range on credit risk identification in corporate bonds investments]. Zeszyty Naukowe Uniwersytetu Szczecińskiego, Finanse, Rynki Finansowe, Ubezpieczenia, 50, 511-526.

Związek Polskiego Leasingu. (2015). Dane Statystyczne [Statistic Data]. Availabel from http://www. leasing.org.pl/statystyki/ 
